\title{
o natural e o construído: a estação balneárea de Araxá nos anos 1920-1940'
}

Glaura Teixeira Nogueira Lima

Doutoranda PUC/SP

RESUMO

Este artigo analisa natureza e cultura a partir da experiência de Araxá, Minas Gerais, tendo em vista a sua construção como estação balneária. Nascida sob o emblema das águas, a cidade absorveu, no seu cotidiano, diversas práticas e representações em torno daquilo que se pretendia: tornar-se, de fato, uma estância hidromineral. O que se desenhou nesse percurso, entre os anos 1920 e 1940, foi a reconstrução de espaços, de tempos e de relações sociais, revelando vários lugares, ora no balneário, ora na cidade, ora nos caminhos que levam até ambos, trazendo significados, regras e hierarquias peculiares a cada um ou semelhantes entre eles.

Palavras-chave: Araxá (MG); Cidadebalneário; Experiências.

\section{ABSTRACT}

This article is based on Araxá, a city in the state of Minas Gerais. It analyzes the nature and culture of the planner's intentions for the construction of a spatown. Araxá was conceived under the symbol of waters. It absorbed many experiences and planned performances to become, in fact, a mineral-water spatown. Along the way, from 1920-1940, the reconstruction of spaces, times and social relations were projected. This revealed areas of interest both in the city and health-resort, and the routes to reach them. At the same time, it revealed meanings, rules and hierarchies they share.

Keywords: Araxá (MG, Brazil); Spa town; Customs.

\section{Araxá}

Entre as minhas saudades uma existe,

Que mais me dá

Com o calor forte, e então me põe mais triste:

É a do Araxá.

Que terras essas! Que formosas terras!

Iguaes não ha! 
Céos infinitos, serras, serras, serras...

No alto, o Araxá.

E o ar puro, o ar fresco e ás vezes frio

Que corre lá!

Que differentes são clima do Rio

E o do Araxá!

Andas triste? Padeces, sobre maguas,

Doença má?

Vae do Barreiro ás milagrosas aguas,

Lá no Araxá.

Vae onde estive já por duas vezes,

Vae já e já

Onde sinto não ir todos os mezes,

Vae a Araxá!

Alberto de Oliveira

Quando o poeta Alberto de Oliveira esteve em Araxá, fazendo estação de águas, pôde também provar a experiência de reunir as atenções da cidade em torno de si. Reverenciado pela posse do nobre título de príncipe da poesia brasileira, conquistado naqueles anos 20, ele retribuiu distinção com amabilidade. Pelas elites foi saudado sobretudo com jantares, flores e discursos. Em contrapartida fez uma conferência literária no Cine Trianon em benefício das obras da Igreja Matriz de São Domingos, que se construía, e escreveu os versos intitulados Araxá. O poema exaltou a terra visitada: a natureza e o poder de cura das suas águas. E foi disseminado ao ser impresso nos jornais, nos almanaques e, mais ainda, ao ser eternizado na memória ou na voz de quem o ouviu, leu e aprendeu a recitá-lo. ${ }^{2}$

Religiosos, políticos, poetas, inventores e cientistas, esse público ampliava-se em direção aos fazendeiros, negociantes, profissionais liberais e militares de alta patente, consubstanciando a sensação de prazer que pulsava no coração dos visitantes. Alguns vinham sozinhos, outros acompanhados das famílias, e todos eles juntavam-se nas varandas dos hotéis, nos salões de refeições ou de jogos, no balneário, nas fontes ou nos espaços públicos da cidade.

Atestar as águas minerais, entre outros poderes atribuídos à estação balneária, tornou-se prática repetida habitualmente. Já nos anos 20, um livro de hóspedes ilustres indicava a presença dos visitantes, muitos deles médicos que, embora estivessem em temporada de lazer com suas famílias, eram chamados a opinar. Julgamentos abalizados de cientistas ou professores em férias, 
vinculados às Faculdades de Medicina do Rio de Janeiro e de São Paulo, avultavam a relação de pareceres e assinaturas em livros mantidos geralmente por hotéis e escritórios de empresas concessionárias das águas, com evidente empenho para reuni-los.

Água e cidade são elementos que se combinam para expressar o significado de um lugar como Araxá. Que cidade é esta, construída tangível e intangivelmente sob este emblema que, por tradição, tem reservado a ela uma identidade tão específica quanto híbrida, formada no modo de vida e nas experiências dos seus moradores e visitantes? Que cidade é esta, centrada em torno do bem que pode trazer prosperidade material e, também, curar, embelezar e trazer fruição?

Araxá (sudoeste de Minas Gerais) é constituída por dois territórios imbricados entre si, porém separados geograficamente por uma via de quatro quilômetros de extensão: o Barreiro - terras originalmente rurais onde se encontram as fontes das águas - e a cidade, espaço urbano propriamente dito, nascido daquele primeiro.

Do natural ao construído percorreu-se um caminho de mão dupla: urbanizar para gerar riquezas, produzir para fazer o uso indicado dos recursos naturais, valorizar o ambiente natural para conquistar o conforto material e, com ele, receber os veranistas que chegavam em busca de lazer e os doentes à procura de tratamento. Diante dessas percepções foi preciso transformar a cidade em balneário, o balneário em cidade (preferencialmente, uma cidadejardim) ou ambos.

Sob o signo de uma sociedade rural e escravista, a cidade de Araxá havia ingressado no processo de transformação espacial, a partir do século XIX, lidando com problemas de toda ordem. Hesitando entre o que já se considerava como uma vocação, a agropecuária, mais um comércio precário, raras formas de aderir às atividades industriais e deficientes meios de comunicação e de transporte, os habitantes locais viram, no potencial das fontes minerais do Barreiro, a perspectiva de assimilarem o ritmo das mudanças impostas pela urbanização.

O espaço urbano constituiu-se no lugar, por excelência, que pudesse representar o rompimento de uma sociedade estabelecida tradicionalmente para inseri-la na nova ordem de transformações. Dotar esse espaço de uma atmosfera tanto higiênica e bela quanto rica e próspera foi a premissa do processo de urbanização então em vigor. A forma de operacionalizar tal predisposição seguiu diferentes práticas de vincular o progresso material à busca inconteste de se alterarem, profundamente, a alma e o modo de vida dos cidadãos. ${ }^{4}$ 
Estavam lançadas algumas das grandes questões da cidade que se constituía como fruto das mais diversas experiências vividas. Em meio ao desafio de aderir às inovações urbanas, Araxá mostrou vários indicadores, simultaneamente, assim como ocorreu com tantas cidades brasileiras. Lado a lado assistiu-se ao confronto da miséria com o indício de opulência que se vislumbrava. ${ }^{5}$ Sinais revelados da luta para resistir às adversidades como a carestia de alimentos, a explosão de epidemias, a carência de moradias e de serviços de saneamento básico com todas as implicações do higienismo-sanitarismo encontrariam perspectivas infinitas de soluções diante daquilo que Araxá poderia vir a ser. ${ }^{6}$ A visão de Saint-Hilaire, registrada por escrito, muito antes focalizara nesta direção:

as águas minerais são límpidas e de cor avermelhada, com um gosto amargo que lembra ao mesmo tempo o de ovos podres. A menção dessas simples características é suficiente para mostrar que elas são sulfurosas e, em conseqüência poderiam ser empregadas na cura de todas as doenças para as quais são aconselhadas águas desse tipo, e em particular das moléstias de pele tão comuns no Brasil.?

Mais de meio século após a passagem do biólogo francês que atestara, com seu olhar científico e europeizado, a possibilidade de uma história a ser construída, Araxá deu início à tentativa de fazer sua estação de águas cuja concretização esteve assinalada pela alternância entre ações práticas e tantos outros adiamentos.

Ao final do século XIX, as revelações das propriedades das águas e do seu valor terapêutico apontaram novas possibilidades quanto à sua utilização. Tais descobertas passaram a representar um novo sentido para os moradores urbanos. O caminho a ser traçado sinalizou para a prática do culto à saúde do corpo e da própria cidade. Para isso os primeiros estudos já garantiam o êxito dos tratamentos. ${ }^{8}$ Bastavam a escolha da estação própria, a presença de médicos especializados e a persistência por parte do paciente. A esse respeito, a citação de exemplos de pessoas que obtiveram a cura e dos aspectos favoráveis a uma vida saudável como o ambiente natural das fontes e a disponibilidade de uma alimentação baseada na carne e no leite, constituíam a imagem de uma estância de futuro. Assim como ocorrera nas cidades hidrominerais perenizadas com a invenção da temporada de vinte e um dias pelos romanos, o Barreiro de Araxá poderia eternizar-se como um lugar de cura. ${ }^{9}$

Ao contrário dos sulistas, que se habituaram ao uso regular do termo estância para denominarem a propriedade rural, Araxá conciliou esta expres- 
são — tanto quanto outra, estação — para referir-se à sua condição de lugar onde se passa uma temporada para tratamento, descanso ou recreio. Ao começar a década de 1930 já se notava ligeira tendência para adotar a primeira, ou seja, estância, fato que se cristalizou com o projeto, implantado durante o Estado Novo, de fazer de Araxá "a maior e mais bela estância hidromineral do continente". ${ }^{10}$

Urbanização, higienismo e salubridade ${ }^{11}$ adquiriram significado relevante na medida em que cada conquista nestas áreas implicava a inserção de Araxá nos modelos estabelecidos de cidade e, em particular, de estação de águas. Da prática higienista à transformação espacial desses territórios, passando pelo incentivo e realização de pesquisas científicas sobre a formação e o uso das águas, abria-se uma via de possibilidades para os habitantes locais.

O projeto modernizador concebido pelos republicanos e implantado no Brasil a partir dos primeiros anos do novo regime atingiu não somente Rio de Janeiro, São Paulo ou Belo Horizonte, mas também outros grandes centros. Diversos lugares apropriaram-se desses modelos, ${ }^{12}$ todos eles inspirados no ideal europeu de civilização. Toda cidade alicerçada nos preceitos da medicina e da engenharia garantiria o propósito de tornar-se tanto aprazível quanto saudável. Concentrando a dupla função de ser cidade e ser estação de cura e veraneio, Araxá acolheu perfeitamente esta tendência que se disseminara pelo mundo ocidental desde o término do século XIX. O impulso à freqüência aos balneários favoreceu Araxá que, enquanto estância hidromineral, uniu as noções de higiene, de saúde física e de embelezamento às circunstâncias inovadoras de trabalho e de lazer. Nada mais pragmático do que buscar condições propícias para oferecer, a quem chega, as águas revigorantes do organismo.

A urbanização e a modernização de Araxá passaram a representar um modelo próprio, ainda que tenha sido produto de um processo amplo de mudanças históricas. A transformação de todo um estilo de viver comum às sociedades tradicionais também seguiu a diretriz vinda das regiões industrializadas, conforme os novos padrões determinados pelo avanço científico-tecnológico. ${ }^{13}$

As águas minerais compunham o patrimônio de Araxá. Através da Câmara, responsável pelos poderes legislativo e executivo, cabia ao município o seu aproveitamento, quer fosse por sua iniciativa enquanto poder constituído ou por concessão do privilégio de uso àqueles que o solicitassem legalmente. O domínio dos terrenos adjacentes às fontes por parte de proprietários particulares e a intenção do poder público de utilizar esses recursos naturais deram início a um longo processo em que imperaram, diante das ambicionadas 
transformações, intensas relações sociais e culturais. ${ }^{14}$ A primeira dessas etapas fora vencida em 1915, quando o poder público local cedeu ao estado de Minas Gerais os direitos sobre as fontes. Em contrapartida, o governo estadual criara a prefeitura de Araxá e se comprometera a fazer do Barreiro uma estância balneária modelar, circunstância que se desenrolará por quase três décadas, até ser inaugurado o complexo hidrotermal nos anos 40.

A partir da década de 1930, Araxá retomou a tentativa de ser, de fato, uma estação hidromineral. Este desejo, sentimento permanente, esteve submetido às constantes mudanças, quer fossem na materialidade dos seus espaços físicos quer fossem na subjetividade dos seus administradores. Desde então percorreu-se um caminho próprio de transformação do Barreiro.

A condição de cidade-balneário pôde ser alcançada através das transformações físicas ou do discurso que gerava continuamente representações das experiências vividas ou das que se esperavam viver. Ancorando-se nessas representações formuladas de criação e recriação de espaços urbanos, próprios de uma cidade destinada à cura e ao veraneio, o processo de gestão do novo balneário teve início a partir de 1937. A unicidade pretendida deparou com o cenário plural existente. $\mathrm{O}$ cotidiano da cidade e os ritmos nele presentes evidenciaram-se por um lado pelo modo de viver dos moradores, dos construtores-planejadores, dos higienistas, dos comerciantes, enfim, dos trabalhadores, e por outro, pelas expectativas dos visitantes, cidadãos e cidadãs que chegavam para as temporadas de banhos, de descanso ou de jogos.

Os usuários das águas, os aquacticos — componentes indispensáveis do cenário local —, contribuíram de maneira intensa para desvelar o hibridismo de uma identidade plural a ser formada. Quem chegava de visita a Araxá recebia a hospitalidade tradicionalmente mineira e uma denominação própria. As formas mais correntes e remotas para identificar o outro transitavam entre estrangeiro, visitante, veranista, curista e turista; esta, com variação para touriste ou, ainda, tourist. Essas expressões, presentes no discurso de jornalistas, hoteleiros, cientistas, construtores e governantes, nas apresentações dos chamados guias termais ou médicos, somavam-se a algumas derivações da palavra água. Portanto, os usuários das águas eram os chamados aquacticos ou aqüistas, predominando a primeira forma. Embora hoje essa expressão tenha sido substituída por turista, podendo ganhar a aparência de algo jocoso, tudo indica que sob a perspectiva dos seus contemporâneos ser um(a) aquactico(a) estava mais próximo de ser incluído como alguém privilegiado socialmente do que de representar algo burlesco.

A experiência da vida urbana e desta em contato com a paisagem natu- 
ral do Barreiro evidenciaram os limites tênues entre um e outro territórios. Originaram situações extremamente ambíguas, possibilitando interpretar diferentes vivências do cotidiano também num e noutro lugares. A busca pela prosperidade material, inspirada no ideal europeu de civilização, prometia romper com toda uma herança sócio-cultural, assegurando a construção de múltiplas imagens e expectativas quanto ao futuro. ${ }^{15}$

A historicidade de Araxá e de sua estação de águas deve ser vista, portanto, como uma reconstrução de tempos, de espaços e de relações sociais. Neste percurso, a interface entre a cidade e o balneário nela contido impuseram-se como algo concreto, mas as sensibilidades inerentes a um e a outro sinalizaram para a subjetividade determinante do formato que a rede urbana ganharia daí por diante. ${ }^{16}$

Considerando que os estilos de vida adotados na cidade são provisionais e devem ser pensados com prudência, a convivialidade entre moradores e visitantes e as atitudes de todos para com os espaços urbanos acabaram por buscar dimensões do social que o mundo racional ignora. ${ }^{17}$

O Barreiro foi naturalmente criado com seus espaços onde brotaram água, lama e demais riquezas naturais. Tantos outros pontos daquela área viram-se culturalmente transformados. Entre o natural e o construído formaram-se o balneário e a cidade como algo complexo, historicamente produzido. Impasses de ambos os lados, em permanente tensão, impuseram formas de viabilizar os meios de beber a água, definiram a maneira ideal para ingeri-la e para usufruir os seus poderes. Os banhos de imersão exigiram igualmente condições propícias ao seu melhor aproveitamento.

Mas, afinal, o que é essa estância e qual sua relação com a paisagem onde se bebe água, toma-se banho e respiram-se os ares aprazíveis? Os hábitos mantidos reproduzem aqueles vistos enquanto modelo de estação balneária? Ser uma cidade-balneário pressupôs produzir uma materialidade a partir da benevolência da natureza. Para intervir com suas práticas sociais, administradores, técnicos, higienistas, empresários e trabalhadores em geral imprimiram conhecimentos e expectativas com o objetivo de fazerem configurar os espaços recíprocos da cidade e do balneário tais como os entendiam e os imaginavam. ${ }^{18}$

Nos primeiros anos da década de 1930, construções agrupadas já abrigavam as fontes, acolhiam visitantes em torno de um quiosque e forneciam energia elétrica através de uma subestação. Ao centro das edificações, a Casa de Banhos reuniu atrativos tanto quanto experiências compartilhadas entre visitantes e funcionários, moradores e ou trabalhadores de Araxá. Jardins sinuo- 
sos, cuidadosamente planejados, uniam cada um dos pontos construídos com suas formas, funções e sentidos. Avizinhando-se desse conjunto, os hotéis, as pensões, os pequenos comércios e as moradias compunham o território do Barreiro, ligado à cidade, desde 1915, pela estrada ainda de terra e por tantas outras propriedades rurais.

O primeiro balneário havia sido construído pela empresa fundada por iniciativa de Thiers Botelho, através da Sociedade Auto-Viação Araxaense ou Botelho \& Cia., constando de cinco repartimentos, sendo três quartinhos, uma sala e um cômodo para fornalha. Um segundo balneário conferiu aspecto renovado à estância. A firma Botelho \& Magalhães (desta vez, restrita a Thiers Botelho e Antonio de Castro Magalhães) contratou o engenheiro Ettore Bertacin - o mesmo que construiu a estrada Araxá-Barreiro e realizou outros projetos urbanísticos para a prefeitura nos anos 20 -, incumbindo-lhe o projeto arquitetônico daquela Casa de Banhos. Agora, sim, uma casa de dezesseis cabines para banho sulfuroso, cabine para banho de lama, sala de espera, sala para administração, consultórios médicos e casa de força garantindo os banhos quentes. ${ }^{19}$

Em 1927, médicos da Sociedade de Medicina e Cirurgia de Uberaba e de Araxá haviam acompanhado o então presidente de Minas Gerais, Antônio Carlos Ribeiro de Andrada, em visita às fontes do Barreiro. De passagem pela então região do Triângulo Mineiro, ${ }^{20} \mathrm{o}$ estadista comprometeu-se a beneficiar a estância de Araxá. O médico João Teixeira Álvares compôs a comitiva e, como estudioso daquelas águas durante quarenta anos e um dos seus primeiros concessionários, considerou-as até aquele momento um tesouro abandonado. Mas o governo dispensava seu olhar ao Barreiro e o Dr. João Teixeira Álvares definiu, então, o prazer pessoal diante das primeiras ações do presidente mineiro:

ver tombar e desapparecer o antigo muro de pedras que cercava as fontes, baluarte intransponível da ignorância, grosseira Bastilha que impedia a entrada do progresso e da vida. ${ }^{21}$

A fonte sulfurosa já se chamava Andrade Júnior desde que esse hidrólogo realizara ali o trabalho definido, à época, como o de captação racional das águas referente à "sua vasão, a sua thermalidade, a sua salinidade”. Até 1932 o dispositivo para retirá-las diretamente da fonte pôde ser descrito como "profundamente ante-hygienico, até mesmo condemnavel, descommodo e inesthetico". ${ }^{22}$ Tratava-se de um cano, nada mais do que isso. A imprensa chegava 
a lamentar a cena em que se viam idosos e reumáticos curvando-se até quase os pés para "colher o copo da bendicta água". ${ }^{23}$

Nos primeiros meses daquele ano, 1932, o desafio para minimizar o sacrifício dos aquáticos junto à fonte fora tão extenuante quanto o de viabilizar financeiramente suas novas instalações. O prefeito, Fausto Soares Figueiras Alvim, recorreu a um filho da terra, o construtor Manoel dos Santos, para executar a obra da Fonte Andrade Júnior, também chamada de Bebedouro, conforme ditava o projeto do engenheiro Raul Brizzi d'Mediolanum. O acordo estabeleceu que o pagamento ao construtor se faria pelo produto da taxa a ser cobrada pelo uso das águas. Posteriormente, essa taxa seria revertida em melhoramentos para a estância tal como ocorria nas demais, "quer nacionaes quer extrangeiras”. A referência contínua a Araxá como reduto de incomparável riqueza hidromineral levou, durante décadas, às inevitáveis associações. Naquele momento, especialmente, esperava-se que a estação de águas se tornasse a "rainha das estâncias brasileiras e uma das maiores do mundo". ${ }^{24}$

Deixar o momento presente para voltar ao passado é viabilizar uma maneira de abrir espaço a um futuro. Dessa forma agiu igualmente o engenheiro José de Carvalho Lopes quando as autoridades locais inauguraram a Fonte Andrade Júnior, de água sulfurosa, ainda na versão anterior à que existe hoje. Em discurso, preocupou-se em pontuar o percurso do patrono da fonte a quem tivera a oportunidade de auxiliar, creditando a ele o devido mérito. Desde 1924, o hidrólogo Andrade Júnior dedicara-se ao estudo geológico do Barreiro depois de ter atuado em várias regiões do país. Em 1926 retornara aos estudos e apontara a radioatividade da outra fonte — a de água radioativa que já se conhecia como Fonte Dona Beja. Dois anos depois, em 1928, novas análises permitiram ao cientista explicar o modo de as águas emergirem e a hipótese da sua origem em fase pré-histórica. Referindo-se à água que corria como um grande trunfo da população, Carvalho Lopes encerrou a fala, a última daquela cerimônia oficial em que cerca de duzentas pessoas o aplaudiram depois de já terem ouvido os pronunciamentos do prefeito e de outros oradores.

A obra definida como um "moderno, lindo e confortavel pavilhão" viera para abrigar a água sulfurosa captada. Seus executores recorreram à lembrança dos nomes que contribuíram para concretizá-la, a saber, o artista, o hidrólogo, o ex-prefeito, o prefeito no período e o engenheiro, respectivamente:

O ilustre artista araxaense Calmon Barreto, prêmio de viagem á Europa e aqui presente, n'um belo gesto que bem define o seu carater, prontificou-se a gravar 
num bronze artístico, que será colocado em frente á fonte, a homenagem a Andrade Junior. Quero que o ilustre artista patrício complete a homenagem com um bronze que também será colocado ao lado da fonte, de mais treis nomes. A justiça nos dita: Mario Álvares da Silva Campos, Fausto Figueira Soares Alvim e Raul Brizzi d'Mediolanum. ${ }^{25}$

O panorama do Barreiro na década de 1930 passou a ser tal qual o de um belo parque. O estabelecimento para os banhos e os abrigos para as fontes radioativa e sulfurosa reinavam em meio aos córregos canalizados com palmeiras e lírios na extensão de suas margens. Nos jardins havia rosas, hortênsias, violetas, fuccias e folhas dos caladiums. ${ }^{26} \mathrm{~A}$ "nova cidade balneário", que se modificava pelo urbanismo, paisagismo e cientificismo dirigido às águas, viu sua historicidade transformada por um espaço de circulação, gerando, por sua vez, tantas outras imagens sobre a vida urbana. ${ }^{27}$

Ser uma estação balneária significava estar integrada à urbanização tal como esta deveria ser. Além da qualidade da água, elementos como luminosidade, pureza de ar, saneamento público, higiene, belas paisagens, ruas e avenidas planejadas eram essenciais. Transportes rodoviário, ferroviário e aéreo também se impunham como componentes indispensáveis.

Ligada ao Barreiro pela estrada de automóveis, a cidade também oferecia estabelecimentos hoteleiros que, associados à vivência de uma estação de águas, davam visibilidade às experiências de homens e mulheres. Tanto uns quanto outras apresentavam um jeito próprio de viver, de trabalhar e de se divertir. Estação de águas, afastada da produção industrial e próxima a uma sociedade conservadora de tradição agrária, suas temporadas de 21 dias agiram como um estímulo às oportunidades de novos produtos e serviços.

O comércio e a indústria compunham-se, principalmente, de lojas de tecidos, de gêneros do país, farmácias, tipografias, salões de cabeleireiro, cafés, confeitarias, casas de frutas, sorveterias ambulantes, fábricas de calçados, fábricas de manteiga e queijo e, ainda, fábricas de sabonetes derivados das propriedades das águas. Dessa forma, as estações de águas, como Araxá, impulsionavam também uma nova indústria: a da propaganda. Assim é que, ao lado de anúncios de hotéis, tratamentos médicos, serviços de costureiras, alfaiates e chapeleiras, entre outros, a imprensa local publicava os nomes de aquáticas e aquáticos em colunas sociais, valorizando sua presença. É esse o enfoque do corpo sob uma perspectiva histórica e, como tal, desde o início do século XX já se ofereciam notas publicitárias com vistas à saúde e ao vigor dos corpos. ${ }^{28}$

A especificidade de Araxá, enquanto estância balneária, reproduziu con- 
tinuamente relações sociais e de trabalho nascidas do contato mantido com o outro mais ou menos distante. A história desse lugar interagiu com tantas relações pessoais quanto as histórias vividas pelos que o freqüentaram periodicamente.

Se as experiências dos moradores, obtidas por meio do exercício de atividades profissionais e vinculadas a uma sucessão de idéias e iniciativas para se implantarem serviços urbanos, promoveram a viabilização da estância, as experiências dos visitantes caminharam em sentido paralelo, com igual proporção. Como expectadores ansiosos por situações inéditas à sua espera, os veranistas asseguravam repouso, divertimento, relaxamento junto ao ambiente natural, tratamento médico, enfim, o tempo do não trabalho.

Por um lado, as pessoas de Araxá adaptavam seu corpo e suas aspirações ao modelo de uma cidade que se queria como estação de águas. Reservavam o sustento a si e às suas famílias, buscando formas de crescimento material que variavam segundo a capacidade de observação e o poder de execução de cada uma. Por outro lado, garantiam a permanência dos que chegavam, colocando-se à disposição para oferecer-lhes o lazer ou a cura.

$\mathrm{O}$ ato de fazer uma estação ou de estar num ou noutro lugar por determinado tempo, neste caso uma estância onde se passa temporada com objetivos de fazer tratamento ou de descansar, pressupõe experiências variadas. Entre o aquático visitante e o morador anfitrião verificou-se a criação de uma via ocupada por elementos que se cruzavam, ora tensionados, ora não. Poderiam ser esses elementos, os hábitos alimentares, os modos de se vestir, de trafegar, de portar-se e tantas outras novas maneiras de pensar, de consumir ou de produzir para o deleite próprio ou para reproduzi-los com fins de comercialização. Essa reprodução, adotada não só como simples prática individual ou familiar mas também como forma de comercializar mercadorias, ganhou mais ou menos força conforme se estabeleceram as particularidades das relações locais, quer fossem sociais, quer fossem de trabalho.

Esses elementos compuseram um feixe cultural, podendo ser tanto aqueles incorporados em virtude do caráter hegemônico que apresentavam, quanto aqueles transmitidos entre gerações. ${ }^{29}$ No dia-a-dia da cidade, as práticas colocadas em evidência como a adoção de um novo corte de cabelo ou do uso de um chapéu, a posse envaidecida de uma fotografia ou de um automóvel ou um ingrediente a mais na feitura do almoço trivial nasciam, muitas vezes, desse relacionamento com o imprevisto. Bem-vinda e, simultaneamente, provocadora de certo estranhamento, a novidade não perturbou a racionalidade, 
abrindo possibilidades para fazer de Araxá, do Barreiro e do caminho entre ambos, uma cidade viva e mítica. ${ }^{30}$

O período dedicado a fazer a estação de águas durava inicialmente vinte e um dias. Os romanos assim o estipularam, haja vista a preocupação voltada para os princípios que eternizariam sua cidade, explícitos no valor atribuído às aparências, tanto no espaço urbano com seus traços geométricos, quanto no corpo, em constante busca pelas formas estéticas, de purificação e de higiene, por eles consideradas as ideais. Criados os estabelecimentos públicos para banhos - as termas romanas —, eles viam no ato de banhar-se uma experiência naturalmente exigida ao cidadão e à cidadã. ${ }^{31}$

As temporadas não eram apenas acontecimentos efêmeros, sem rastro. A fugacidade da programação, seguida a princípio durante três semanas (às vezes mais, às vezes menos) como privilégio e poder do veranista, não passava incólume ao habitante local ainda que pudesse parecer-lhe cronologicamente reduzida. Longe disso, o período de convívio com quem chegava para depois partir — não raro, com a esperança do retorno - dotava a cidade de um ritmo passível de absorver todos os movimentos próprios de um lugar onde se podia estar por algum tempo com todos os seus sentidos, também os metafóricos.

Esse período de permanência na estância representava para os aquáticos um intervalo em suas vidas, objetivando o reequilíbrio do organismo. A consciência do tempo vivido no dia-a-dia, muitas vezes desgastante, enfadonho e, sobretudo, uniforme, parecia quebrar-se ou retardar o seu fluxo ao usufruir a estação de águas tranqüila e longínqua como Araxá.

Na chegada já se obtinha a sensação da amplitude e do vigor do que seriam aquelas semanas tão especiais. Os hábitos diferentes então introduzidos levavam ao esquecimento do mundo deixado para trás. Já aclimatado após a primeira semana, o visitante sentia o tempo passar fugaz e rapidamente. Já se vivia a nova monotonia conquistada e, ao contrário do que se pensa, os dias pareciam breves no seu conjunto. ${ }^{32}$

Afora os benefícios absorvidos durante três semanas de tratamento e tranqüilidade, a viagem em si significava o rompimento da rotina. Experiência decorrente não apenas do interregno mas também da distância geográfica que separava o visitante, temporariamente, dos seus afazeres da vida cotidiana. E quanto maior o percurso avançado, maior o esquecimento do lugar onde se vive sempre.

"A estação thermal cria uma medicina physica e suggestiva do mais feliz exito", garantiu uma espécie de guia do usuário, em 1920 — "sobretudo quan- 
do como no Araxá, onde, a paisagem é nova e encantadora e cujas águas e clima são de peregrinas virtudes". ${ }^{33}$ Durante as viagens longas aconselhavam-se aos aquáticos - especificamente, aos doentes — não fazê-las ininterruptas. Com paragens esparsas aliviava-se a distância, e o provável desconforto não seria sentido pelos visitantes saudáveis. Das estações férreas de Sacramento e de Uberaba partiam automóveis para conduzir todos à estância de Araxá em poucas horas. Como garantia aos passageiros, faziam questão de divulgar a existência de telefones ao longo do percurso.

Para aquele que vivia no Rio de Janeiro, naqueles anos 20, nada mais nada menos do que trinta horas de viagem o separavam de Araxá. Partindo de São Paulo, o tempo gasto contabilizava vinte horas. Do Rio de Janeiro, pela Estrada de Ferro Central do Brasil, mais especificamente da estação central da capital da República, partiam três trens diários para a capital paulista: um diurno e dois noturnos. Às sete horas da manhã de cada dia o passageiro tinha à sua disposição a primeira e a segunda classes, com bilhetes de ida e volta intervalados em trinta dias. À noite partia um trem com carro-dormitório cujos leitos ofereciam preços mais acessíveis, seguido de outro, três horas depois, porém de luxo. Estes dispunham de cabines com dois leitos e um carrorestaurante. Até aí consumiam-se cerca de onze horas de viagem.

Da estação da Luz, em São Paulo, saíam dois trens: um ao amanhecer e outro, anoitecendo, com baldeação em Campinas uma vez que a chegada coincidia com os horários dos trens da Companhia Mogyana em direção a Sacramento ou a Uberaba, já em Minas Gerais. Da mesma forma que ocorria nos percursos anteriores, as passagens davam o direito à volta, com a baldeação acrescida da estação de Ribeirão Preto. O porte e o estilo das cidades pelas quais passavam os trilhos contavam a favor dos trens. Havia restaurantes nessas estações também, embora tanto a Central do Brasil como a Mogiana dispusessem desse serviço nos próprios vagões ou carros, os chamados carrossalões. No caso da estação de Sacramento, a viagem exigia, nesse ponto, que se tomasse um bonde elétrico até a cidade distante quatorze quilômetros da estrada de ferro, percorridos em trinta minutos. ${ }^{34}$

Nestas terras mineiras, onde se viam chapadões, serras e campos, os passageiros cumpriam por estradas de automóveis os trajetos entre Sacramento e Araxá ou Uberaba e Araxá. No primeiro deles, procedente da cidade sacramentana, um Fiat chegava à estância hidromineral nos dias pares do mês para retornar nos dias ímpares. A empresa Auto-Viação Sacramento-Araxá, responsável por esse serviço de condução dos passageiros, pertencia a um negociante conhecido regionalmente como Coronel José Afonso de Almeida, 
com representante em Araxá, através da firma José da Cunha \& Cia. Com o italiano Domingos Zema, motorista da referida empresa no início dos anos 20, onze pessoas - de acordo com a capacidade dos carros - chegavam em quatro horas a Araxá, contabilizando paradas nos pontos previamente estabelecidos ao longo da estrada como Ventania, Alpercatas e Poções. O trânsito livre, sem pedágios, para os autos da viação concessionária, assim como para carros de bois e caminhões, colaborava para agilizar a viagem daqueles que preferiam o roteiro via Sacramento. ${ }^{35}$

Alguns aspectos contribuíam para fazer do percurso de 88 quilômetros um caminho aprazível e um orgulho a mais para os donos do negócio. A estrada, margeada por linha telefônica, possibilitava ainda o conforto de um telefone portátil em cada automóvel. Para oferecer maior comodidade, as bagagens seguiam à parte em carros destinados apenas para transportá-las.

As viagens exibiam um calendário próprio com base, evidentemente, nos horários de todos os trens da Mogyana. A cada dia ímpar, às 4 horas da manhã, partia de Araxá um automóvel da empresa do Cel. José Afonso. Os passageiros embarcavam rumo a São Paulo na estação do Cipó em Sacramento, às 10 horas e 30 minutos, passando por Ribeirão Preto, de onde saía o noturno das 21 horas e 30 minutos para chegar à capital paulista às 9 horas e 40 minutos do dia seguinte.

Outras opções abriam-se para aqueles que pudessem contar com motoristas particulares ou eventualmente contratados para essas viagens. Eles conduziam os passageiros de Araxá a Ribeirão Preto, de onde partia um trem às 7 horas e 30 minutos com chegada a São Paulo prevista para as 19 horas e 15 minutos. De lá ao Rio de Janeiro partiam trens às 7 horas e às 20 horas, com chegadas às 18 e às 7 horas e 40 minutos da manhã seguinte, respectivamente. Outra locomotiva, de luxo, oferecia a opção das 21 horas e 5 minutos para chegar ao Rio de Janeiro às 8 horas e 25 minutos. Estava assim concluído o trajeto de volta ao início da linha férrea, isto é, do Rio de Janeiro a São Paulo.

Tal qual o percurso de Sacramento a Araxá cumpria-se o caminho entre Uberaba e Araxá por meio de empresas arrendatárias desse privilégio, uma vez que a estrada de ferro ainda não alcançava diretamente a cidade. Pela viação de Thiers Botelho chegavam de Uberaba, em dias alternados da semana, os automóveis com passageiros que haviam embarcado nos trens da Mogiana ou nos da Oeste de Minas, vindos de Belo Horizonte. Durante o ano de 1922, esse roteiro esteve arrendado a Domingos Zema, já desligado da Auto-Viação Sacramento-Araxá, que o fazia em 5 horas, conduzindo três pessoas no seu 
Ford modelo T-1914. Às 5 horas e 30 minutos, ele partia de Uberaba nos dias pares para retornar no mesmo horário, no dia seguinte, em dias ímpares. ${ }^{36}$

Salvo os imprevistos geográficos e climáticos ou os desafios de transpor estradas de cascalhos, pontes, mata-burros e bueiros, algumas dificuldades se impunham: transitar por elas enquanto propriedade particular, pioneira, e no caso da estrada Araxá-Uberaba, aberta sem subvenção estadual, implicava pagamento de pedágio. Em 1927 custava 10\$ o ingresso de cada passageiro de automóvel particular, custo baixo se comparado a outros. Essa prática se refletiu nas relações entre os poderes públicos constituídos e os direitos privados de concessionários e passageiros, gerando conflitos de empresários e motoristas com fazendeiros e prefeitos da redondeza.

A estrada ligando essas duas cidades começara a ser gestada em 1917, como parte das ações da Botelho \& Magalhães, a mesma que arrendara, desde o início de 1916, do estado de Minas Gerais o direito de uso das fontes de águas minerais, incluindo a construção do balneário e dos jardins do entorno. Tendo Thiers Botelho à sua frente, acompanhado por Antônio Castro Magalhães e José Botelho, a empresa chamada Auto-Viação Araxá-Uberaba abrira a linha de automóveis na condição de construtora de estradas particulares, viabilizando ainda contatos com Patrocínio, cidade próxima, e mais os distritos de Dores de Santa Juliana (Santa Juliana) e Conceição do Araxá (Perdizes), à época pertencentes a Araxá.

Perfazendo o total de 162 quilômetros entre Uberaba e Araxá, Thiers Botelho e seus sócios cumpriam essa distância disponibilizando aos visitantes carros Ford modelo T, Chevrolet e Fiat, uma linha de jardineira e mais os citados serviços de telefonia prestados ao longo do percurso, acrescidos da instalação de uma "caixa postal particular ao Correio das cidades por onde passava a estrada".

Em outro sentido, passando por Belo Horizonte, os trens noturnos saíam diariamente do Rio de Janeiro às 18 horas e 30 minutos para chegarem às 10 horas e 5 minutos na capital mineira, de onde partiam para Araxá às 16 horas. Disponibilizando dormitórios e restaurante, o desembarque dos passageiros na plataforma da estação da Oeste acontecia às 10 horas e 5 minutos do dia seguinte. ${ }^{37}$

A estrada de ferro mineira veio oferecer essa linha incluindo nela a opção do desembarque em São Pedro de Alcântara (Ibiá), até 1926, quando foi então inaugurada a estação de Araxá e com ela a possibilidade de alcançar diretamente a cidade através dos trilhos. No sentido Uberaba-Araxá havia, ao final dos anos 20, nove estações, dentre as quais se destacam as de Presidente 
Bernardes, Tamanduapava, Capivara, Ibitimirim, Itaipu, Alpercatas, Almeida Campos e Zelândia.

Pouco depois de inaugurada a estação férrea de Araxá na praça que, posteriormente, se chamou Arthur Bernardes - referência ao mineiro na presidência da República (1922-1926) —, teve início a construção de um ramal (ferro-carril) para o Barreiro, porém, não concluído. Coube à prefeitura, em 1928, organizar outro meio de transporte ligando a cidade à sua estância. Era um serviço regular de auto-omnibus feito em um Chevrolet de dez lugares. Entre as seis horas da manhã e as cinco da tarde realizavam-se oito viagens de ida e volta, ao preço de $1 \$ 000$ cada uma.

Ainda assim, as questões em torno dos caminhos que ligavam Araxá à capital mineira ou ao estado de São Paulo criavam sérios desafios. No início dos anos 30, a estrada Araxá-Sacramento já pertencia ao governo de Minas Gerais, mas encontrava-se à espera de conservação e reparos diante do grande fluxo de mercadorias e de passageiros que por ela transitava. A prefeitura local mantinha serviços de conserto da estrada e dos seus telefones. Para executá-los, não raro os funcionários municipais aproveitavam a corrida dos motoristas da Viação Araxá-Sacramento. Mas a condução, a princípio gratuita, acabava por custar aos cofres públicos. Requerimentos caíam sobre a mesa do prefeito Fausto Alvim solicitando descontos e, outras vezes, abatimentos nos impostos a serem pagos sobre a propriedade dos automóveis. A prefeitura, por seu turno, abria outra estrada rumo à fronteira com os paulistas, cujas referências indicam ser essa a Estrada da Liberdade, construída em parceria com o hoteleiro italiano Francisco Cavallini. ${ }^{38}$

Os caminhos até Araxá e os meios de transitar por eles aguçaram intensos debates na Câmara Municipal. Em 1936, a minoria dos vereadores locais votou contra a maioria favorável ao aumento tributário sobre automóveis e caminhões particulares ou de aluguel. Esse tema fez parte da primeira reunião pós-eleitoral daquele ano e ganhou repercussão ainda maior ao chegar à população em forma de comunicado distribuído pelas ruas da cidade. ${ }^{39}$

O poder público local defendia o acesso a Belo Horizonte por meio de uma estrada a ser aberta entre Araxá-Ibiá-São Gotardo até encontrar-se com outras já existentes no oeste mineiro. As linhas férreas e rodoviárias seriam acrescidas, ao começar a década de 1940, pela linha aérea da Panair. Todas as terças e sextas-feiras chegava-se a Araxá de avião, ainda pela manhã, duas horas e cinqüenta minutos após o embarque no Rio de Janeiro e passando por Belo Horizonte. Pelo mesmo avião, à tarde, era possível cumprir o trajeto de 
volta. As passagens ficavam à venda na respeitável casa comercial da cidade — Baroni \& Cia —, agentes locais da Panair. ${ }^{40}$

Ao final dos anos 40, a comunicação aérea já se fazia não apenas pela Cia. Nacional de Transportes Aereos com os vôos para Belo Horizonte e Rio de Janeiro, mas também pela Viação Aerea São Paulo — Vasp, para São Paulo. Sem considerar as ligações rodoviárias, os trens diários para Belo Horizonte e Uberaba asseguravam o transporte de passageiros entre Araxá e essas cidades, agora não mais pela Oeste de Minas, transformada em Rede Mineira de Viação a partir de 1931.

Pelos trilhos, pelos ares ou sobre rodas dava-se o deslocamento até Araxá. Paisagens novas levavam passageiros de diferentes cidades aos ambientes naturais ou construídos do local das fontes onde se revelavam não apenas a cor da água, o cheiro do balneário, mas também a ausência de ruídos eminentemente urbanos. Os aposentos tidos como mais ou menos confortáveis dependiam da referência daqueles a que se estavam habituados, distantes até centenas de quilômetros. As condições dos hotéis podiam mostrar o retorno a um tempo já conquistado ou ainda por conquistar. Quem sabe, talvez, Araxá se configurasse como um objetivo a ser alcançado pelos paulistanos que, neste caso, poderiam ter como modelos as antigas residências da avenida Paulista representando em si os estilos de estação de águas e de cassinos. ${ }^{41}$

A princípio, essas temporadas de 21 dias recebiam orientação médica para ocorrerem preferencialmente nos meses de março, abril ou setembro. ${ }^{42}$ Acreditavam os especialistas que eram esses os períodos mais apropriados, embora não se descartassem os demais. Aos usuários das águas e de outros elementos convenientes da estância reservavam-se vastos benefícios disponíveis, uma espécie de férias em que se podiam contemplar o seu e os outros tipos de vida e, ainda, refletir sobre eles.

Os divulgadores da estância de Araxá, especialmente os médicos e os hoteleiros, havia muito depositavam confiança na idéia auspiciosa de respirar um novo ar, o componente essencial destinado aos visitantes. Para aqueles que viviam a poucos metros acima do mar, a altitude em torno de mil metros poderia evocar prazeres indescritíveis, conceder proventos incalculáveis. A temperatura amena fazia do clima um dado obrigatório em qualquer anúncio publicitário de hotel ou de consultório médico.

Aliada aos fatores climáticos, a variação de lugar, alterando hábitos ou incorporando outros, tornava-se vital ao alívio do ritmo em crescente tensão nos centros urbanos. Araxá poderia oferecer aquilo que a cultura das cidades 
grandes havia excluído. São Paulo, Rio de Janeiro e Belo Horizonte já haviam deixado para trás a tranqüilidade, $\mathrm{o}$ ar puro e a alimentação saudável.

Ao doente, em especial, uma vez instalado no hotel escolhido, recomendava-se não fazer o uso das águas imediatamente. A regra consistia em esperar entre vinte e quatro e quarenta e oito horas, no mínimo. Depois de acomodado, o período sugerido permitia-lhe adaptar-se aos novos hábitos e, seguramente, aclimatar-se. ${ }^{43}$ Enquanto isso, cumpria-se a fase preparatória do tratamento, avalizada pelo discurso poético do cronista anônimo:

E não somente as águas os únicos elementos de cura que se concentram em Araxá. Alliam-se-lhes também, num complemento nunca assas admirado, factores outros que nenhuma outra estancia reune tão completos.

O clima é duma amenidade acariciadora e a natureza, cheia de encantos, eleva o observador de deslumbramento.

O seu céu, sempre muito azul, faz devanear perdendo-se a consciência do tempo que passo... E quem se envolve na claridade alacre do seu esplendido sol tão amigo, sempre irisando as verduras em redor; quem respira o seu ar saturado de odor calido das flores, á luz tepida de uma eterna primavera, que faz desabrochar os renovos numa florescencia que nunca se entorpece - não pode deixar de se inebriar. Nessa esplendorosa festa das coisas, presa dessa indefinível sensação de esperança, que, por si só, já é mais de meia cura para os que soffrem.... ${ }^{44}$

As águas compunham um método complexo de terapêutica cujos elementos formadores deveriam agir harmoniosamente. Havia muito que os pesquisadores aliavam o seu valor à qualidade do clima e ao regime alimentar próprio a ser indicado pelo médico. Fossem elas para ingerir água radioativa ou sulfurosa, fossem para imersão, as estações indicavam ainda o repouso - um misto de descanso com dieta alimentar — como recurso eficaz ao tratamento ${ }^{45}$ Creditava-se a cura termal, portanto, aos elementos climáticos, à altitude, à vegetação, enfim:

às mudanças de vida, pautadas durante a estação segundo normas sanitárias especiaes, entre as quaes avultavam a dieta e o exercicio - enfim a agua thermal com as suas condições physico-chimicas peculiares, utilisada pelos varios processos da technica hydriatica. Os agentes curativos encabeçam-se pois em clima, regime e aguas. Os sedentários de vida escravisada a um ar recluso, falho no oxygenio, infestado de impurezas; os quebrantados de nutrição, de desassimilação lenta, com as vísceras trophicas do estomago ao fígado paralysadas; os flagela- 
dos de hypocondria, encontram no Araxá o seu meio reconfortador por excellencia: o bom solo, o bom ar; a boa agua, esse triplo alicerce da saúde, proclamado desde Hyppocrates. ${ }^{46}$

A urbanização conduzia à sociabilidade e com esta incorporavam-se novos padrões de comportamento como a sensação de bem-estar adquirida em decorrência da mudança de ambiente. E, no episódico, residia o caráter saudável do novo hábito. Os poderes das águas poderiam rejuvenescer, revigorar o corpo, adiando os efeitos provocados pelo passar dos anos. ${ }^{47} \mathrm{~A}$ busca pela hidroterapia e o isolamento para evitar contágio ou para simples repouso levaram homens, mulheres e crianças aos bons ares das estâncias. No caso da experiência de Araxá há ainda uma particularidade. Concebida posteriormente às demais do Sul de Minas, como Poços de Caldas, Caxambu, São Lourenço e Cambuquira e, sobretudo, distante geograficamente do tradicional circuito mineiro de águas e dos grandes centros do país, ainda assim, a cidade habituou-se a receber anualmente um grande número de visitantes.

A busca da cura por meio das águas atuava como referencial estratégico da estância que se projetava, a partir das mudanças verificadas na própria concepção de cidade, sob a ótica higiênico-sanitarista. O convívio com o outro dava-se nos pontos de circulação como os salões dos hotéis, a sala de recepção do balneário ou o coreto e os jardins do parque. Nos espaços públicos urbanos não havia como isolar-se completamente dos habitantes locais, contudo evidenciavam-se outras formas de isolamento como contraponto da socialização. $\mathrm{O}$ fato de atrair pacientes em busca de cura, qualquer que fosse esta, representava também permitir-lhes que se isolassem em face da recuperação pretendida. Havia, então, os aposentos dos quartos em que os hóspedes garantiam privacidade. Da mesma forma, as cabines de banhos e as áreas verdes mais reservadas dentro do próprio parque ou, ainda, mais distantes nos entornos do Barreiro e da cidade:

Nos arredores do Barreiro ha passeios encantadores. Caçam-se perdizes e codornas nos arredores das serras do Monte Alto e Bocaina ... Em summa, quer a doentes, quer a sãos, é altamente proveitosa uma estação no Araxá. ${ }^{48}$

Nada mais adequado, portanto, do que praticar a metáfora do corpo durante as temporadas, se possível com 21 dias, período em que o organismo e a sociedade deveriam funcionar em harmonia. ${ }^{49}$ Tendo o corpo como referência, trabalhando-o internamente, buscavam-se os sentidos dos banhos..$^{50}$ Entre a ingestão de doses diárias de água obtidas nas fontes sulfurosa e ra- 
dioativa, intercaladas com passeios a pé unindo os dois pontos, o rito do banho ocupava lugar de relevo no relógio diário do Barreiro. ${ }^{51}$ Pela manhã, o tempo vivido ali, segundo o modo de ocupação adotado pelos usuários da estância, fazia da prática desse costume um conjunto de simbolismos representado pelo zelo com uma série de aspectos então expostos: higiene, limpeza, vestuário, saúde e longevidade. A água turva e espumante permitia um tipo de ocultamento em meio ao isolamento proporcionado pela banheira. ${ }^{52}$ Fora dela, os corpos podiam revelar a manifestação das experiências obtidas por meio de outras linguagens: as relações de pudor, de estranhamento e os sistemas de valores diante de novas descobertas.

Águas de beber ou de banhos, límpidas e incolores, juntavam-se à lama, produto gelatinoso de cor negra e cheiro próprio, formado "nos reconcavos das rochas junto as fontes, em contato com a região". Os preços dos banhos de lama eram usualmente mais elevados do que os demais. Se acompanhados do banho medicinal - mais demorado - e em temperatura a partir de $36^{\circ} \mathrm{C}$, exigia-se a prescrição médica, diferentemente dos banhos de higiene pessoal.

O fato é que a aquae originada da fonte - herança dos hábitos da antiguidade - fazia que os aquáticos permanecessem por uma longa temporada na estação. As formas de sociabilidade mantidas entre aquáticos e moradores locais e destes com hoteleiros, comerciantes e profissionais liberais contribuíram para desenhar a cidade e o Barreiro com identidade própria. O cotidiano de Araxá viveu sua fixidez mesmo quando se percebiam as manifestações espontâneas. A quebra do seu ritmo com as temporadas de banhos significou a existência mútua entre a regularidade e a espontaneidade de uma estação de águas. ${ }^{53}$

A proposta de tentar traçar as formas que assumiram essas transformações no âmbito do espaço urbano, das representações que envolvem a cidade e sua estância de cura, de repouso e de veraneio, das identidades, das práticas assumidas por diversos segmentos sociais, das memórias de quem viveu ou ainda vive esse cotidiano é o mote desta pesquisa ainda em andamento.

O sentido da viabilização do sonho da estação balneária com o seu coroamento durante o Estado Novo, através de uma suntuosa obra, pode ser percebido pelas leituras que dela fazem os aquacticos(as) ou visitantes, e os moradores(as) de Araxá. Os primeiros chegaram atraídos pela possibilidade de usufruir descanso, divertimento e também tratamento médico num ambiente natural, sadio e, ao mesmo tempo, considerado propício ao lazer. Os demais, habitantes permanentes da cidade e do Barreiro, viveram situações impactantes. Durante muito tempo eles presentificaram as mudanças construindo diversas imagens do que seria a estância ideal..$^{54}$ 


\section{NOTAS}

${ }^{1}$ Este texto é parte de uma pesquisa mais ampla, em andamento, referente ao curso de doutorado na PUC/SP, com financiamento pelo CNPq.

${ }^{2}$ CARVALHO, Horácio. Álbum de Araxá. São Paulo: Typographia Gutemberg, 1928. p.4.

${ }^{3}$ CHARTIER, Roger. O mundo como representação. Revista Estudos Avançados, São Paulo, v.5, n.11, jan.-abr. 1991.

${ }^{4}$ BERMAN, Marshall. Tudo que é sólido desmancha no ar: a aventura da modernidade. Trad. Carlos Felipe Moisés e Ana Maria L. Ioratti. São Paulo: Companhia das Letras, 1986.

${ }^{5}$ MATOS, Maria Izilda de. Cotidiano e cultura: história, cidade e trabalho. Bauru: Edusc, 2002.

${ }^{6}$ DELEUZE, Gilles; PARNET, Claire. Diálogos. Tradução de Eloísa Araújo Ribeiro. São Paulo: Escuta, s.d.

${ }^{7}$ SAINT-HILAIRE, A. A. Viagem às nascentes do rio São Francisco. Belo Horizonte: Itatiaia, 1975.

${ }^{8}$ CAMINHOÁ, J. M. Estudo das Aguas Mineraes do Araxá. Rio de Janeiro: Typographia De Laemmert \& Cia., 1890.

${ }^{9}$ Antonio Candido adota a referência de lugar de cura para dirigir-se às célebres estações européias que serviram de cenário para a recuperação da saúde por meio das águas ou para vilegiatura, de não menos célebres personagens encontrados na literatura e na história. In: RIO, João do. A correspondência de uma estação de cura. 3.ed. São Paulo: Scipione, 1992.

${ }^{10}$ A partir do período em questão, Araxá teve seu nome associado a esse lema, com fins de divulgação.

${ }^{11}$ Segundo Foucault, salubridade é "o estado das coisas, do meio e seus elementos constitutivos que permitem a melhor saúde possível”. É nesse sentido que o autor insere o conceito de higiene pública enquanto técnica utilizada para controlar e modificar o meio em que vivem os indivíduos e do qual depende a sua saúde. FOUCAULT, Michel. Microfísica do poder. Rio de Janeiro: Graal, 1984. p.93.

${ }^{12}$ SALGUEIRO, Heliana Angotti. Revisando Haussmann: os limites da comparação. A cidade, a arquitetura e os espaços verdes: o caso de Belo Horizonte. Revista USP, São Paulo, v.26, 1995.

${ }^{13}$ ROLNIK, Raquel. História urbana: história na cidade? In: Cidade \& história, São Paulo: [s.n.], [s.d.]. p.27-9.

${ }^{14}$ WILLIAMS, Raymond. Marxismo e literatura. Trad. Waltensir Dutra. Rio de Janeiro: Zahar, 1979.

${ }^{15}$ PESAVENTO, Sandra Jatahy. O imaginário da cidade: visões literárias do urbano: Paris, Rio de Janeiro, Porto Alegre. Porto Alegre: Ed. UFRGS, 1999. 
${ }^{16}$ MATOS, Maria Izilda Santos de. Âncoras de emoções: corpos, subjetividades e sensibilidades. Bauru: Edusc, 2005.

${ }^{17}$ MENEZES, Ulpiano Toledo Bezerra de. Fontes visuais, cultura visual, história visual. Balanço provisório, propostas cautelares. In: Revista Brasileira de História, São Paulo: Anpuh, v.23, n.45, 2003.

${ }^{18}$ Idem. Morfologia das cidades brasileiras: introdução ao estudo histórico da iconografia urbana. Revista USP, São Paulo, n.30, jun.-ago. 1996. Partindo do pressuposto de que a cidade é um artefato, o autor define tal caracterização como um segmento da natureza socialmente apropriado que se coloca invariavelmente como produto e vetor sujeito a um campo de forças nas práticas orientadas pelas representações sociais.

${ }^{19}$ EDE, Martha Botelho. Thiers: controvérsia de três tempos. Belo Horizonte: Mazza, 2004.

${ }^{20}$ Araxá não mais pertence à região do Triângulo Mineiro, como no passado. Com a redivisão do estado passou a pertencer à região do Alto Paranaíba.

${ }^{21}$ Carta Aberta enviada pelo médico Dr. João Teixeira Álvares ao presidente do estado de Minas Gerais, Olegário Maciel, publicada no jornal A Opinião. Araxá, n.13, 10.04.1932, p.4. Arquivo SAPP/FCCB.

${ }^{22}$ A Opinião. Araxá, n.9, 13.03.1932, ano 1, p.4. Arquivo SAPP/FCCB.

${ }^{23}$ A Opinião. Araxá, n.10, 20.03.1932, ano 1, p.3. Arquivo SAPP/FCCB.

${ }^{24}$ Ibidem.

${ }^{25}$ A Opinião. Araxá, n.11, 27.03.1932. Arquivo SAPP/FCCB.

${ }^{26}$ A Opinião. Araxá, n.13, 10.04.1932, p.4. Arquivo SAPP/FCCB.

${ }^{27}$ PECHMAN, Roberto Moses. Os excluídos da rua: ordem urbana e cultura popular. In: BRESCIANI, Stella (Org.) Imagens da cidade: séculos XIX e XX. São Paulo: Anpuh/Marco Zero/Fapesp, 1994.

${ }^{28}$ BERNUZZI, Denise. Corpo e história. In: Cadernos de subjetividade. São Paulo: Programa de Estudos Pós-Graduados em Psicologia Clínica da PUC-SP, v.3, n.2, set.1994-fev.1995, p.243-66.

${ }^{29}$ Thompson chamou de feixe o conjunto de vários elementos culturais que são incorporados ao longo dos contatos mantidos em determinada comunidade ou transmitidos por tradição. THOMPSON, E. P. Costumes em comum. São Paulo: Companhia das Letras, 1998. ${ }^{30}$ CERTEAU, Michel. A invenção do cotidiano. Petrópolis: Vozes, 1994.

${ }^{31}$ SENNET, Richard. Carne e pedra. Trad. Marcos Aarão Reis. 3.ed. Rio de Janeiro: Record, 2003. p.6-23. Ver também Antonio Candido prefaciando João do Rio in: RIO, João do. Correspondência de uma Estação de Cura. 3.ed. São Paulo: Scipione, 1992. p.IX-XVIII.

${ }^{32}$ MANN, Thomas. A montanha mágica. 2.ed. Rio de Janeiro: Nova Fronteira, 2000. p.143-5. 
${ }^{33}$ Guia Thermal das Águas do Araxá. Estado de Minas Geraes, s.n., 1920. p.9-14.

${ }^{34}$ CERCHI, Carlos Alberto. Os bondes de Sacramento. Uberaba: Pinti, 1991. p.93-104.

${ }^{35}$ CASTRO, Maria Beatriz Afonso de. Zema: a história de um nome. Araxá: Santa Adélia, 1994. p.22-52.

${ }^{36}$ Ibidem, p.58. De 1926 em diante, a linha férrea já alcançava Araxá, mas essa estrada manteve o trânsito até 1936 quando o governo mineiro construiu, de maneira rústica e penosa, a Araxá-Belo Horizonte. Em 1932, Thiers Botelho cedeu os poderes do direito que possuía à prefeitura de Uberaba e recebeu indenização do governo federal. EDE, op. cit., p.64.

${ }^{37}$ A essa época, final dos anos 30 e início dos anos 40, os noturnos saíam de São Paulo às 19 horas e 30 minutos, chegando a Sacramento (via Campinas e Ribeirão Preto) às 15 horas do dia seguinte. Meia hora depois partiam os automóveis rumo a Araxá. Thermas de Araxá: informações úteis sobre a estância. Araxá: Officinas Cabral, s.d. 16p.

${ }^{38}$ Requerimentos/ACM/SAPP/FCCB.

39 "Comunicado ao Povo" - sobre a reunião da Câmara, discussão e voto de vários projetos. 26.11.1936. PO/0092-141/AMDB-03/SAPP/FCCB.

${ }^{40}$ Thermas de Araxá. Informações úteis sobre a estância. Araxá: Officinas Cabral, 1941. p.14.

${ }^{41}$ Sobre as impressões causadas por mudanças de espaços, de tempos e de hierarquias sociais, ver LÉVI-STRAUSS, Claude. Tristes trópicos. Trad. Rosa Freire d’Aguiar. São Paulo: Companhia das Letras, 1996. p.69-134.

${ }^{42}$ Com o passar do tempo e com ele a incorporação de novos hábitos, as temporadas em Araxá seriam sugeridas para 14 ou 7 dias. Thermas de Araxá. Informações úteis sobre a estância. Araxá: Officinas Cabral, 1941. À medida em que as investigações científicas se avolumavam as temporadas passaram a ser recomendadas para todos os meses do ano. O PAIZ, 08/03/1929. Triângulo Mineiro — Impressões de Araxá.

${ }^{43}$ Guia Thermal das Águas do Araxá. Estado de Minas Geraes, s.n., 1920. p.16.

${ }^{44}$ CARVALHO, op. cit., p.60.

${ }^{45}$ MATOS, Maria Izilda Santos de. Cotidiano e cultura: história, cidade e trabalho. Bauru: Edusc, 2002.

${ }^{46}$ Guia Thermal das Águas do Araxá. Estado de Minas Geraes, s.n., 1920. p.43.

${ }^{47}$ Às situações ocasionais obtidas nessas temporadas, ou seja, vividas nesse passar do tempo e que nos fazem unir ou distanciar-nos de algo, Certeau chamou de tempo acidentado. CERTEAU, Michel de. A invenção do cotidiano. Petrópolis: Vozes, 1994. p.311.

${ }^{48}$ CARVALHO, op. cit., p.57. 
${ }^{49}$ VIGARELLO, Georges. O limpo e o sujo: uma história de higiene corporal. São Paulo: Martins Fontes, 1996.

${ }^{50}$ Ibidem, p.310; PORTER, Roy. História do corpo. In: BURKE, Peter (Org.) A escrita da história - novas perspectivas. São Paulo: Ed. Unesp, 1992. p.291.

${ }^{51}$ THOMPSON, op. cit., p.19.

${ }^{52}$ CORBIN, Alain. Saberes e odores. São Paulo: Companhia das Letras, 1987.

${ }^{53}$ HELLER, Agnes. O cotidiano e a história. Trad. Carlos Nelson Coutinho e Leandro Konder. 6.ed. São Paulo: Paz e Terra, 2000. v.2.

${ }^{54}$ CALVINO, Ítalo. As cidades invisíveis. Trad. Diogo Mainardi. São Paulo: Companhia das Letras, 1990. 